to achieve a more fully continental account. In other articles focusing on the region, she uncovered the roles of American merchants in the Atlantic trades after the British Abolition of the slave trade. More significantly, Romero provided critical evaluation of previously assumed understandings of Africa's historical experience by reframing the historical geography, for example, pointing out the Swahili Coast's closer connections with the Indian Ocean world than with the rest of sub-Saharan Africa. Bucking the common patterns of broad narratives, she studied local societies such as Lamu (Kenya) in their local interpretations, as well as crisscrossing global connections. In this manner, she provided for the study of women as a subject of diversity and dynamism, distinct from previous histories that collapsed African women into a single category. Romero emerged as an innovative leader in contemporary thoughts about redressing Eurocentric writings and dismantling dominant narratives-the driving force behind the refashioning of World History beginning in the 1980s. Dr. Romero's theories are reflected in the works of a new generation of African historians focusing on close subjects such as family histories, slave agency, women's biographies, and domesticity.

Colleagues remember her as being exceptionally productive and dynamic, particularly considering her personal circumstances. Patricia Romero leaves three sons: Jeff and his wife, Laura Elliott; Arthur and his wife, Donna, and their children, Tyler and Julia; and Stephen and his wife, Belinda, and their two children, Ryan and Stevie. $₫$

DOI:10.1017/rms.2016.144

Kimberly Katz and Oluwatoyin Oduntan Towson University

\title{
John Ruedy
}

1927-2016

John "Jack" Ruedy was an illustrious historian of Algeria, an inspiring mentor, a teacher of great gifts, the founding director of a long-flourishing M.A. program, and a man for whom principle was not a matter of convenience. A Francophile who came to the study of French colonialism in Algeria as the result of an impromptu sail from the south of France to that country while still a student. Jack then engaged deeply with the Maghreb, an interest and commitment that began with his book Land Policy in Colonial 
Algeria (1967), and ultimately culminated in the writing of Modern Algeria: The Origins and Development of a Nation in 1992. This latter book has endured as a seminal account of the theories and practices of settler colonialism in Algeria, often cited and serving as the springboard for much later work on Algerian history. His research interests in colonial land policies also led him to make an early and signal contribution to Palestine studies in a chapter, "The Dynamics of Land Alienation," he contributed to Ibrahim Abu-Lughod's The Transformation of Palestine in 1971.

Ruedy was the kind of mentor who inspired his doctoral students by the genuine interest he took in new ideas and approaches. His was a nimble and curious intellect. Osama Abi-Mershed recalls a tutorial in which he and Ruedy together explored the theoretical horizons of postcolonial theory: "I was particularly rewarded by Prof. Ruedy's enthusiasm for this multifaceted literature, and deeply marked by his candidness in revising a few of his former reflections on colonial and national historiography. Indeed, he quickly began to incorporate 'postcolonial' paradigms and concepts into his ongoing research, namely his biographies of prominent jeunes algériens like Ferhat Abbas and Chérif Benhabylès. Since then, I have always done my best to follow Prof. Ruedy's example and pay homage to his refreshing openness to new learning and new ideas." Another of the doctoral students he mentored, Henri Lauzière, speaks of his warmth, the ways in which he connected with his students: "Most of my interactions with him were in French. When we were by ourselves, we rarely spoke English, if ever. He would bring me over to the faculty club (where he had his usual glass of red wine over lunch) and we would talk about his time in the Maghreb or his time in Paris attending Jacques Berque's lectures (of which no student could make sense, apparently)." Ruedy made Georgetown a go-to place for graduate study of the history of North Africa, and these former doctoral students are making their mark in the field.

Ruedy was also an exceptionally inspiring teacher. Several generations of Georgetown students crowded into his History of the Arab-Israeli Conflict, a course that he handled with a sensitivity and historical depth that disarmed and educated even the most partisan. As Kevin Martin, who served as his TA, remarks: "It was a great privilege to watch him lecture to undergraduates on modern Middle East history, particularly the Arab-Israeli Conflict. Clear, concise, passionate, and in absolute command of the facts and the context, he set a consistent standard that I would be proud to claim I have matched on a few days of my teaching career." Another of his former TAs, Chris Toensing, echoes this sentiment: "In the classroom, he was a master lecturer, capable of combining analytical heft with telling detail and infusing his narration of 
distant events with genuine drama. It was not uncommon for his students to be spellbound. I have never heard another like him." Ruedy was also a highly appreciated lecturer at the Foreign Service Institute of the U.S. Department of State for much of his career, and chair of its Advanced Area Studies Seminar on Northern Africa from 1984 to1991. His talents in the classroom were recognized by the Department of History at Georgetown some years ago with the establishment of the John Ruedy General Education Award, given each year to a graduate student who excels as a lecturer in a large introductory class.

Ruedy also shouldered more than his share of administrative service. He was the founder and then served for thirteen years as the director of the Master of Arts in Arab Studies (MAAS) program, the first such program in the country. He played a major role in the design of the curriculum, and many of the hallmarks of MAAS still bear his imprint, especially his insistence on mastery of Arabic. He also instituted his belief that knowledge of the contemporary Arab world, its politics and economics, required sustained study of its history and culture as well.

Jack was also known for his joie de vivre. He was a hiker and a runner, having taken up the latter after the death of von Grunebaum in 1972-he said he aimed to live longer than his advisor. He was a wine connoisseur, and one of the many losses we experienced at Georgetown with his retirement was the departure of fine French reds from our faculty meetings. He always spoke with the utmost affection about Nancy Carson Ruedy, his wife and favorite travel companion of 63 years. Jack is remembered by his students and colleagues as not only good company, but also as an extraordinarily decent man. "A generous and caring mentor," "unassuming, fair-minded, an attentive listener always ready with helpful advice and a distinctive, endearing laugh," a man of "profound decency, kindness, and great humor"this is his legacy as voiced by many. I arrived at Georgetown in 1983 as a young woman, unsure of her place in what was then a mostly older and male department. Jack treated me as a respected colleague from the first moment we met and never seemed to notice my age or gender. Like so many others, I am deeply grateful for the support he gave me and for the example he set.

DOI:10.1017/rms.2016.143

Judith E. Tucker Georgetown University 